\title{
Proposed Bylaws of
}

\section{Western European Specialists Section}

Editor's Note: The following proposed bylaws will be toted on at the 1980 ALA Annual Conference.

\section{Article I, Name}

The name of this organization shall be the Western European Specialists Section of the Association of College and Research Libraries.

\section{Article II. Object}

The Section shall represent those librarians in the Association of College and Research Libraries (ACRL) who specialize or are otherwise professionally involved in the acquisition and use of information sources originating in or relating to Western European countries. This Section shall act for the ACRL, in cooperation with other professional groups, in regard to those aspects of library service that require special knowledge of sources from or concerning Western Europe.

\section{Article III. Membership}

Any member of the ACRL may elect membership in this Section. Every member has the right to vote. Any personal member is eligible to hold office.

\section{Article IV. Meetings}

Sec. 1. Annual Meetings. The Section shall hold an annual business meeting at the time and place of the Annual Conference of the American Library Association.

Sec. 2. Special Meetings. Special meetings of the Section may be called at the discretion of the Executive Committee. All members of the Section shall receive notification of a special meeting at least one month prior to the scheduled date of the meeting.

Sec. 3. Quorum. Twenty members shall constitute a quorum for any meeting of the Section.

\section{Article V. Officers}

Sec. 1. Officers. The officers of the Section shall be a chairperson, a vice chairperson/chairperson-elect, the immediate-past chairperson, and a secretary.

Sec. 2. Terms. All officers shall serve for a term of one year which ends at the adjournment of the annual meeting.

Sec. 3. Vacancies. In the event of a vacancy in the office of chairperson, the vice chairperson/ chairperson-elect shall succeed to the office of chairperson and shall continue in that office until the expiration of the term for which he/she was originally elected to serve as chairperson. If the office of secretary becomes vacant, the chairperson shall appoint a member of the Section to that office. A vacancy in the office of vice chairperson/chairperson-elect shall be filled only by election.

\section{Article V1. Executive Committee}

Sec. 1. Composition. The Executive Committee shall consist of the officers, the chairpersons of standing committees, and one member-at-large elected for a one-year term.

Sec. 2. Powers and Duties. The Executive Committee shall conduct the business of the Section during the period between annual Section meetings. At each annual Section meeting the chairperson shall report on the work of the Executive Committee, at which time that work shall be subject to review by the membership of the Section.

Sec. 3. Meetings. Regular meetings of the Executive Committee shall be held at the times and places of the Annual and Midwinter meetings of the American Library Association. Special meetings may be called at the discretion of the chairperson. Only members of the Executive Committee may vote at Executive Committee meetings, although all Executive Committee meetings shall be open to all members of the Section.

Sec. 4. Quorum. A majority of members constitutes a quorum at any meeting of the Executive Committee.

\section{Article V'II. Committees}

Sec. 1. Standing Committees. Standing committees to consider matters of concern to the Section that require continuity of attention may be authorized by the Section at the annual Section meeting. The size, name, and purpose of a standing committee shall be specified at the time of its authorization. Members of a standing committee shall serve overlapping terms of two years each. In order to set in motion a rotation of committee members, however, some of the initial members of a newly established committee shall be appointed for terms of three years. A member of a committee may be reappointed for a second term and for a third term, but no person shall serve more than three consecutive terms on a single committee. The vice chairperson/chairpersonelect shall appoint committee members to fill the vacancies due to occur during his/her term as chairperson. The vice chairperson/chairpersonelect shall also designate the chairpersons of all committees which will function during his/her term as chairperson of the Section. Unexpected vacancies on a committee shall be filled by a special appointment made by the chairperson of the 
committee with the approval of the chairperson of the Section. A standing committee may be discontinued by a majority vote of the members present and voting at an annual Section meeting.

Sec. 2. Special (Ad Hoc) Committees. Special committees for the performance of particular assignments may be appointed at any time by the chairperson after consultation with the other members of the Executive Committee. Such special committees shall be discontinued at the end of the term of the chairperson who appointed them unless extended by the new chairperson. No special committee shall continue to function for more than two years without authorization by the Section.

Sec. 3. Discussion Groups. Informal discussion groups, to meet under the auspices of the Section at the time and place of the Annual or Midwinter meetings of the American Library Association, may be formed by any five or more members of the Section with the approval of the chairperson.

\section{Article VIII. Nominations and Elections}

Sec. 1. Nominations. The vice chairperson/ chairperson-elect shall appoint a Nominating Committee of at least three members, designating one member as Committee chairperson. No member of the Nominating Committee shall be currently serving on the Executive Committee. The Nominating Committee shall choose a slate of at least two nominees for each of the offices of (a) vice chairperson/chaimerson-elect, (b) secretary, and $(c)$ member-at-large. Additional nominations for these offices may be made by petitions signed by no fewer than five Section members. Nominations put forth by the Nominating Committee, as well as any additional nominations made by petition, shall be filed both with the Executive Secretary of the ACRL and with the secretary of the Section within the deadlines prescribed for nominations by the ACRL. All nominees must be members in good standing of the Section and must consent to candidacy in writing.

Sec. 2. Elections. Elections shall be conducted by mail ballot. For each office, the candidate receiving a plurality of the votes cast shall be elected. In case of a tie vote the successful candidate shall be determined by lot

\section{Article IX. Amendments}

Sec. 1. Proposals. Amendments to these Bylaws may be proposed in writing by the Executive Committee, by a committee appointed specifically for the purpose, or by any five members of the Section. Proposals shall be filed with the secretary at least three months before the annual meeting.

Sec. 2. Notification. A copy of any proposed amendments to be voted upon at the annual meeting shall be mailed by the secretary to each member of the Section at least thirty days before the annual meeting or shall be announced in $\mathrm{Col}$ lege \& Research Libraries News in an issue appearing prior to the annual meeting.

Sec. 3. Voting. An amendment approved by two-thirds of the members voting in a mail vote or by two-thirds of the members present and voting at an annual meeting of the Section shall be carried.

\section{Article X. General Provisions}

Wherever these Bylaws make no specific provisions, the organization of and procedures in the Section shall correspond to those set forth in the ACRL Constitution and Bylaws.

\section{Article XI. Temporary Provisions}

These Bylaws shall take effect upon the adjournment of the meeting at which they are adopted.

\section{OCLC Manuscript Inputters}

If anyone currently inputting manuscripts into OCLC is interested in forming a manuscript user group (MUG) for an informal exchange of information, questions, and answers, please contact the Manuscripts Department, Archives-Manuscripts Division, Ohio Historical Society, 1-71 at 17th Ave., Columbus, $\mathrm{OH} 43211$

\section{Out of Stock? Back Orders?}

If your wholesaler has long delays in completing "out of stock" and "back orders", why not try the firm that specializes in this area. Current imprints are easy to deliver but it takes a personalized, specialized attention to give you reliable service on back list or other hard-toget items.

At Book House we call it "Con. cerned Service" and it works every day for a growing clientele includ. ing academic libraries just like yours.

- Call 517-849-2117 Collect -

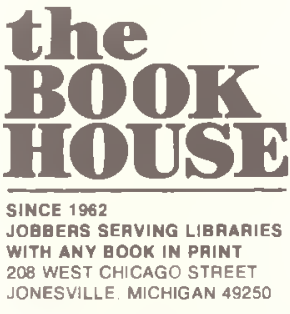




\section{ACRL SURVEYS LIBRARIES ON FEDERAL COOLING CONTROLS}

Fifty-eight of 102 academic libraries polled by ACRL plan to request exemptions from the federal regulations on building temperature controls issued last summer.

The regulations impose a limit of seventy-eight degrees on air conditioning in nonresidential buildings. Libraries are not exempt from the regulations but may claim exemptions individually to protect "materials."

To determine how academic libraries are coping with the regulations, ACRL sent questionnaires to the libraries that are participating in the ACRL 100 Libraries Project. (These libraries have agreed to complete a brief questionnaire four times a year on key areas of library policy and practice.)

Sixty-five percent of the university libraries and 62 percent of the college libraries responding to the questionnaire plan to ask for exemptions from the seventy-eight-degree air-conditioning limit. Only 40 percent of the community college libraries plan to ask for exemptions.

Of the fifty-eight libraries that want exemptions, thirty-three report that their parent institutions are willing to claim exemptions on their behalf; fourteen said that they had not yet asked the parent institutions to claim an exemption; and eleven indicated that they had asked for, but not yet received, a positive answer from university or college authorities.

More than half (thirty of fifty-eight) of the libraries that plan to claim exemptions actually cooled their buildings below seventy-eight degrees last summer. Most of the remaining set their air-conditioning thermostats at seventy-eight degrees last summer, but hope to lower their thermostats below seventy-eight degrees next summer.

How low do they want to set their airconditioning thermostats? If it were their decision to make, most libraries would cool building spaces to seventy degrees or lower, especially in the areas that house special collections, microforms, and audiovisual materials. Twenty-nine of fifty-eight thought that bookstacks should be air-conditioned to seventy degrees or cooler, forty-two of fifty-eight believed that special collections areas should be cooled to seventy degrees or cooler, and thirty-three of fifty-eight believed that spaces housing microforms and audiovisual materials should be kept at seventy degrees or cooler.

Forty-four libraries of the 102 that responded do not plan to ask for exemptions. It is noteworthy that, among these forty-four, twenty-two said they would set cooling temperatures below seventy-eight degrees in at least part of the library if the decision rested with them. Moreover, ten of the forty-four do not have air conditioning.

Nearly 70 percent ( 74 of 102) of all the libraries polled reported that humidity control is important for preserving library materials in their geographic areas. Thirty-eight percent said that they regulate humidity levels in the library buildings during the summer; 35 percent reported that they control humidity during the winter. Most try to keep relative humidity within a range of $\mathbf{4 0}$ percent to 60 percent.

Although a majority of the libraries polled want to be exempted from the federal cooling controls, nearly all the libraries are participating in efforts to conserve energy in their library buildings Sixty-six of 102 libraries questioned had reduced the levels of illumination in their buildings (by using fewer or dimmer lights); forty-nine had reduced ventilation in the building (by lowering the percent of fresh air or by turning off ventilation at night); twenty-four had installed computer monitoring of heating, ventilating, and cooling in the building, eighteen had turned off or turned down the hot water; fourteen had installed major improvements in the heating, ventilating, and cooling system; and eight had put in more efficient lights.

Libraries also reported that they had conserved energy by: adjusting door closures to ease operation, applying a film to windows to reduce glare, putting on a new insulated roof, installing a special cover for outside windows to reduce heat loss, and drawing cool air into the buildings at night and then letting the buildings heat up during the day.

One library director, however, was not altogether optimistic about the potential for energy saving in his building. "Our library," he wrote, "has a very wasteful and inefficient heating and cooling system, although it is only ten years old. The only way to improve it is to dynamite the whole business."

\section{Law and Political Science Section}

In June the chair and chair-elect of the Law and Political Science Section sent to all section members a questionnaire about the aims and activities of the section. Will all those who have not yet returned the questionnaire please send their responses to Tillie Krieger, Chair, LPSS, c/o Boys Town Center for the Study of Youth Development, Boys Town, NE 68010. 
Inside Washington by James D. Lockwood AIA Washington Office

College Iibrary Resources program: As it stands now, Congress will cut funds for the College Library Resources program (Title II-A of the Higher Education Act) from last year's figure of $\$ 9,975,000$ to $\$ 4,987,500$ this year. This reduction means that the average basic grant will fall from $\$ 3,900$ to $\$ 2,000$.

A bill to reauthorize the Higher Education Act (IEA) programs, including Title II-A, has reached the House floor. The bill, which amends and extends HEA for five years, would increase the maximum basic grant under the College Library Resources program from the current $\$ 5,000$ to $\$ 10,000$. In the Senate the prospects for reauthorizing II-A are uncertain because the Appropriations Cormittee has been reluctant to fund the program unless it is targeted to reach only needy institutions.

The ALA Washington Office is hopeful that need criteria can be worked out for the II-A program and that, on this basis, Congress will agree to reauthorize the program. On October 4, ALA witnesses Ann Tumer, Charles Churchwel1, and Thomas Galvin testified before the Senate Subcomittee on Education, Arts, and Humanities in support of all the Title II programs.

National Periodicals Center (NPC): In a surprise move, the sponsors of the House bill reauthorizing HEA included an amendment that would create a National Periodicals Center (NPC). The bill containing the NPC proposal is now on the House floor. When the Senate education subcomittee held hearings on the reauthorization of HEA on October 4, ALA president Thomas Galvin, NCLIS chair Charles Benton, University of Washington at St. Louis librarian Charles Churchwell, and ARL president Connie Dunlap testified in favor of NPC, but subcomittee chair Senator Claiborne Pell (D-R.I.) held back from comitting himself to a periodicals center, saying that any action before the White House Conference would be premature.

Tax Iricentives for Donations: The Senate Finance Subcomittee on Taxation and Debt Management held hearings on October 22 on a bill (S.1078) reinstating a tax incentive for authors and artists who donate their literary, musical, or artistic compositions or papers to a library or museum.

\section{NCIIS Supports Decentralized NPC}

At its September meeting in Colorado the National Commission on Iibraries and Information Science endorsed the NPC legislation that has been introduced in the House. But the commission also moved that its testimony at Senate hearings on NPC should recommend that NPC legislation reflect the implications of the "System C" model contained in a study of NPC by the consulting firm of Arthur D. Iittle. The Little study, which was comissioned by NCLIS, concluded that an INC with a large centralized collection was an idea whose time may have come and gone. As an altemative, the study outlined a "System C" NPC that would provide location and switching services for heavily used items (with private services supplying the actual documents) and build a backup collection for items not elsewhere available. 


\section{One-stop access to over 178,000 current doctoral dissertations!}

Now available - the Comprehensive Dissertation Index 5-Year Cumulation 1973-1977, the definitive reference work which combines the dissertations of the last five years into one concise 19-volume bibliographic index. Any dissertation can be located in minutes!

This is the only single-source reference to over 178,000 current North American doctoral dissertations, making it a valuable addition to any university or other research-oriented library. Keyword and keyphrase indexing within broad subject areas allows users to pinpoint a specific title or browse an entire subject area.

In addition to the complete 19-volume set, Science and Humanities packages are available to meet specialized needs. You can order the CDI 5-Year Cumulation 1973-1977 in either library-bound or microfiche editions.

For complete information and an order form, send in the coupon below with no obligation.

University Microfilms International

300 N. Zeeb Road

Ann Arbor, Michigan 48106

Please send me complete ordering information for the CDI 5-Year Cumulation 1973-1977.

NAME

INSTITUTION

ADDRESS

CITY STATE ZIP

TELEPHONE

(area code) 


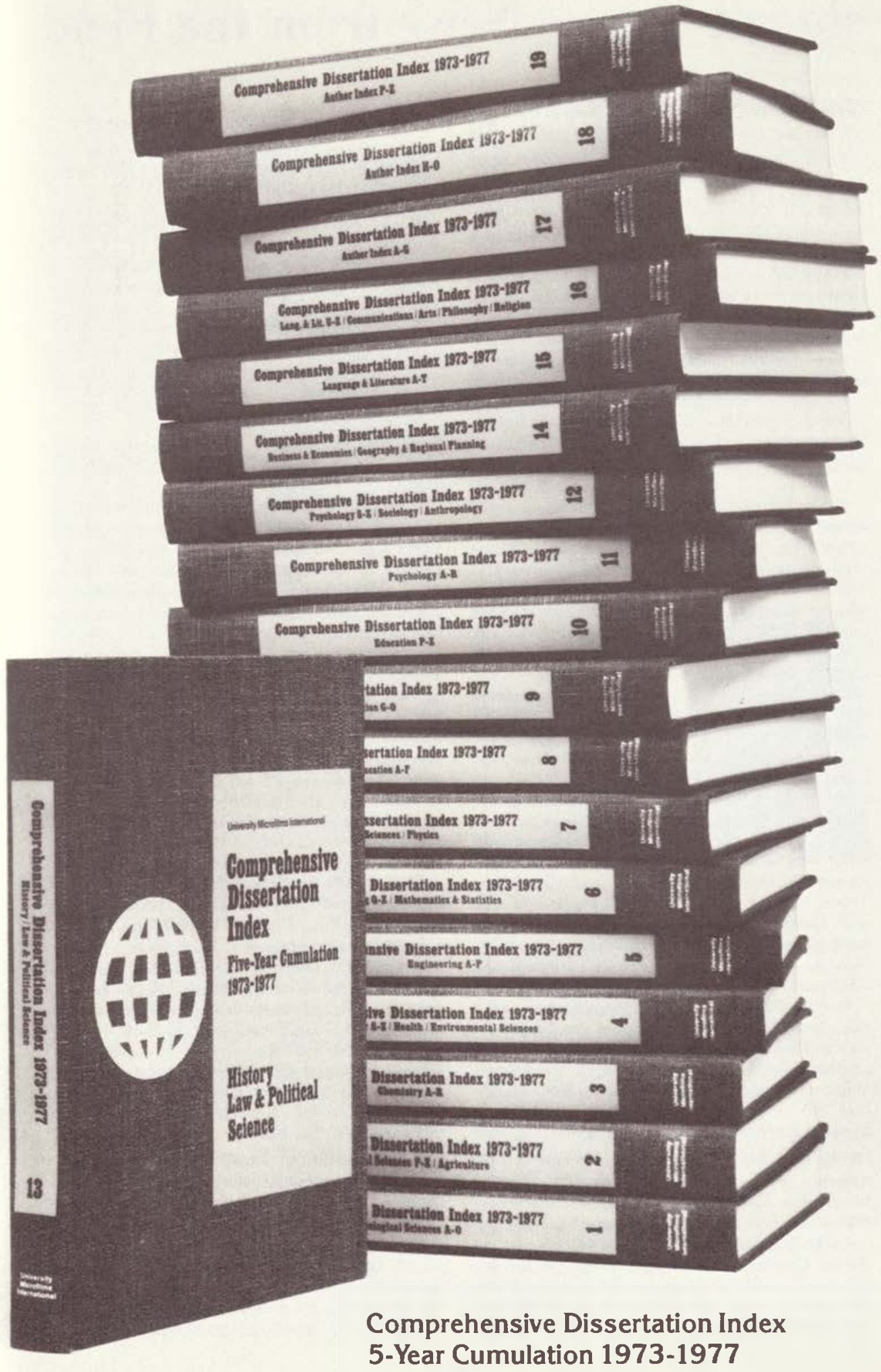

